\title{
Acupuncture, the Black Panther Party, and People's Medicine
}

\section{An Interview with Physician-Activist Tolbert Small}

\author{
Daniel Burton-Rose | ORCID: 0000-0002-7852-1872 \\ Department of History, Wake Forest University, Winston-Salem, NC, USA \\ burtond@wfu.edu \\ Yi-Li Wu | ORCID:0000-0003-4375-0672 \\ Department of Women's and Gender Studies and Department of History, \\ University of Michigan, Ann Arbor, MI, USA \\ yiliwu@umich.edu
}

\begin{abstract}
Tolbert Small (b. 1943) is a physician and civil rights activist best known for his advocacy for research on sickle cell anemia. In the summer of 2020 two of Asian Medicine's editors, Daniel Burton-Rose and Yi-Li Wu, interviewed Small about his clinical career of more than fifty years. The interview focuses on Small's experience with acupuncture, the practice of Chinese medicine in the United States, and his commitment to social justice. Small was introduced to acupuncture in 1972 as a member of a delegation of the Black Panther Party to the People's Republic of China, and he incorporated it into his clinical practice upon his return to Oakland, California. Small began practicing acupuncture at a time when instructional materials and therapeutic implements were difficult to obtain. He witnessed the gradual mainstreaming of Chinese medicine in the United States, accompanied by problems of differential access based on race and income.
\end{abstract}

\section{Keywords}

Tolbert Small - Black Panther Party - People's Republic of China - acupuncture 
Tolbert Small has spent most of his long life at the intersection of health care and social justice activism. Small was born in 1943 in Coldwater, Mississippi. His parents moved the family northward to Detroit, Michigan, a few months after his birth, de facto refugees of the grim quotidian realities for African Americans in the segregated "Jim Crow" South. ${ }^{1}$ Small became a civil rights activist while still in his teens, cofounding a student chapter of the National Association for the Advancement of Colored People at the University of Detroit in 1961. In 1964, as a member of Friends of SNCC (the Student Nonviolent Coordinating Committee), ${ }^{2}$ Small raised money for Mississippi Freedom Summer campaign workers. He himself spent a week at the Democratic Convention in Atlantic City, New Jersey, urging the Democratic Party delegates to seat the Mississippi Freedom Democratic Party, which was headed by the charismatic organizer and Small's family friend Fannie Lou Hamer (1917-77).

Small began his medical training in 1964, graduating from the Wayne State University School of Medicine four years later. He moved to the West Coast the same year, beginning an internship at Highland Hospital in Oakland, California, in 1968. In Oakland, Small worked closely with the Oakland Direct Action Committee, a civil rights organization run by Mark Comfort (1934-76). Comfort had worked with the SNCC campaign in Lowndes County, Alabama, which first employed the black panther icon as a Black Power symbol to combat white rule at the ballot box. ${ }^{3}$ With permission from SNCC organizer Stokely Carmichael (1941-98; later Kwame Ture), Comfort transmitted the black panther iconography to Oakland, where it was adopted by Bobby Seale and Huey Newton in 1966 for their Black Panther Party for Self-Defense. The Panthers soon rose to regional and national prominence with their mediagenic program of armed self-defense of the Black community against police violence. Small met Party member June Hilliard at the Black Panther Party headquarters on Grove Street in West Oakland and offered his medical expertise.

Small never joined the Party, but he became central to Seale's initiative to found People's Free Medical Clinics (PFMC) in every city with a Panther chapter. The East Bay Free Clinic initially bore Seale's name upon its official opening on April 24, 1971, ${ }^{4}$ but the name was soon changed to commemorate George

1 For a magisterial history of the Great Migration, see Wilkerson 2010.

2 The classic account of SNCC is Carson 1981.

3 On the Lowndes campaign for Black enfranchisement, see Jeffries 2009.

4 A flyer announcing "The Grand Opening of the Bobby Seale People's Free Health Clinic" is reproduced in Nelson 2011, 91. 
Jackson (1941-71), the imprisoned Panther "field marshal" and bestselling author, after he was gunned down in an escape attempt at San Quentin State Prison on August 21, 1971.

Small also became the medical director of the Party's new Sickle Cell Anemia Foundation, a groundbreaking program that provided screening for the painful and incurable genetic condition that disproportionally impacted people of African descent. He established testing stations locally, using his contacts in the East Bay medical community to secure supplies and laboratory testing access. He also lobbied nationally to raise awareness about the disease, which contributed to increased attention from medical philanthropies and the federal government.

As the primary physician of the Party in the Bay Area in the early 1970s, Small made house calls on both sides of San Francisco Bay. This work included visiting Angela Davis in jail and George Jackson in the high-security Adjustment Center at San Quentin. Small's medical services to the Black Panther Party continued until approximately 1974.

Small's pioneering work in sickle cell anemia screening has been documented in Alondra Nelson's seminal study of the Panthers' health activism, Body and Soul: The Black Panther Party and the Fight Against Medical Discrimination (2011); a prize-winning book for which Small served as a key informant. ${ }^{5}$ The element of Small's career of most potential interest to readers of Asian Medicine, however, has received little attention. This is Small's practice of acupuncture in the United States after he observed acupuncture anesthesia during a Black Panther Party delegation to the People's Republic of China from March 5 to April $11,1972 .{ }^{6}$ In response to recent calls for increased acknowledgment of the place of African Americans in the adaptation and dissemination

5 Nelson provides detailed accounts of the PFMC s and the sickle cell anemia campaign: Nelson 2011, $75^{-1} 5^{2}$. Her brief discussion of the $197^{2}$ China delegation on pages $7 \mathrm{O}^{-} 71$ and $256 \mathrm{n} 4$ merits the following corrections: (1) the trip spanned from March to April, not just March; (2) there were twenty delegates, not eighteen; (3) Emory Douglas - not "Henry Douglas" (p. 70) or "Henry Douglas Jr." (p. 256n4) - was the Party's minister of culture and a member of the delegation. These errors stem from the only contemporary article Nelson cited on the delegation: "Black Panther Party Members on Way to China" 1972. Additionally, Angela Davis was not a member of the delegation (p. 71).

6 The delegation included twenty members: half were Party members; the other half, like Small, were not. All are named in "Progressive Americans, Led By Panthers, Return from China" 1972; nineteen are identified in a delegation picture reproduced as figure 2 in Meng 2021a, 278. Due to the proximity of "Progressive Americans" 1972 to the events described, we give it priority over different details provided for delegate numbers and trip duration that appeared in later interviews. For another contemporary journalistic account, see Montgomery 1972. 
of acupuncture in the United States, ${ }^{7}$ we have conducted this interview to bring Small's story to an international audience of scholars of Asian medicine. In doing so, we build on the accounts of various journalists who profiled Small over the years, his students and colleagues such as David Bacon and Alex Feng, and the archival work of Eana Meng, whose photo essay on Small in this issue complements the present interview. ${ }^{8}$

Small's involvement with acupuncture can be summarized as follows. The Panther delegates on the 1972 trip to China observed acupuncture anesthesia during a surgery in Beijing and again in Shanghai. Small then requested to personally experience acupuncture from a Chinese physician. At that point, while still in China, Small and at least one other delegate acquired needles and an electrical stimulation machine and began practicing on themselves. This prompted their Chinese hosts to offer them lectures on Traditional Chinese Medicine (Тсм). This was the modernized form of historical indigenous practices that had been codified in the 1950s under the purview of Chinese physicians trained in biomedicine, the product of a hybridization process that had been ongoing since the first decade of the twentieth century. ${ }^{9}$ Small was the only accredited physician in the twenty-person delegation, and these lectures delivered in both Chinese and English - were of special interest to him. ${ }^{10} \mathrm{He}$ recorded the English-language lectures and approximately four hours of audio recordings survive.

After Small returned to Oakland, David Bacon approached him regarding a manuscript titled Basic Acupuncture Techniques. Bacon was a volunteer at the Panther medical clinic overseen by Small as well as a family friend of Anola, Small's wife at the time. Basic Acupuncture Techniques was a translation of Zhongguo zhenjiuxue gaiyao 中国针炎学概要 (lit., Essentials of the Study of Chinese Acupuncture), which Bacon had acquired from China Books in San Francisco and of which he had commissioned a translation. In a letter dated December 30, 1972, which survives in Small's archive, Bacon asked Small to meet and discuss the book in particular and strategies for promoting acupuncture in the United States more generally. Small authored an introduction for Basic Acupuncture Techniques, which was then published by Basic Medicine

\footnotetext{
7 Dandridge 2020.

8 American Association of Acupuncture and Oriental Medicine et al. 2007, 23; Meng 2020a, 2021a. An earlier interview that covered Small's exposure to acupuncture in China is "Dr. Tolbert Small: Journey of a People's Doctor" 2002.

$9 \quad$ On the hybridization process, see Xu 1997; Andrews 2014; Lei 2014.

10 For an idea of what TCM was probably like when presented to Small in 1972, see Sivin 1987.
} 
Books, a nonprofit organization Bacon established and on the editorial committee of which Small served.11

Over email Bacon shared the following recollection of this time:

I remember vividly sitting in the George Jackson People's Free Medical Clinic in the evening, after clinic hours, practicing on ourselves. I was the clinic pharmacist (not with a credential, of course), and when we started I got a set of needles, as did some of the other clinic workers, so that we could learn. We did it the Maoist way - finding the points on ourselves by looking at charts, including ones that Bert [Small] brought back from China.... He also brought back an electrical point stimulator that was used for points on the ear. That was what he used to begin treating drug withdrawal symptoms. It was part of the whole Barefoot Doctor philosophy, I guess, which fit in with the whole $\mathrm{MCHR}^{12}$ radicalism of healthcare workers of the time. ${ }^{13}$

In 1980, Tolbert and Anola Small cofounded the Harriet Tubman Medical Clinic in East Oakland. It served community members until 2016. After his retirement, Small continued to treat patients at the Native American Health Center in Oakland.

The following interview was conducted by Asian Medicine editors Daniel Burton-Rose and Yi-Li Wu on July 15 and September 8, 2020, over Zoom, with Small joining from his home office in Oakland. It has been edited for clarity. In cases in which the documentary record or other individuals mentioned provided corrections, changes have been made to the interview transcript with the permission of the interviewee.

\section{Interview}

Burton-Rose: To begin at the beginning, is it fair to characterize your family as part of the Great Migration?

\footnotetext{
11 The title page of Basic Acupuncture Techniques is reproduced as figure 10 in Meng 2021a, 286.

12 Medical Committee for Human Rights, which was organized to treat civil rights workers during the Mississippi Freedom Summer campaign. On MснR, see Dittmer 2009.

13 David Bacon, electronic correspondence with Burton-Rose, July 18, 2020. Quoted with permission. On barefoot doctors, see Fang 2012. For a photograph of Chinese doctors practicing acupuncture on themselves, see Hsin 1973, 19.
} 
Small: Hell yes! [Laughs]. My father went to Detroit because he had a brother there and he got tired of the Jim Crow shit in the South. That's the story.

Burton-Rose: What year did you begin your medical training in Detroit?

Small: I started medical school [at Wayne State University] in 1964 and I finished in 1968. When I was there, I was the only Black student. What happened was all the medical schools wanted Hill-Burton money. ${ }^{14}$ Part of the reason for Hill-Burton money was that you couldn't discriminate. Charles Wright, a prominent Black gynecologist - founder of the African American Museum [in Detroit] ${ }^{15}$ - wrote Senator [Philip A.] Hart that Wayne State was practicing apartheid and he should stop giving them money. Senator Hart investigated and they said they'd stop practicing apartheid because they wanted the money. ${ }^{16}$ Now they have a very large Black student body. In fact, the guy who used to be head of Alabama's SNCC was their dean of admissions. ${ }^{17}$

Burton-Rose: Did you ever have any official relationship with the Medical Committee for Human Rights, the physicians' group that came out of the Mississippi Freedom Summer campaign?

Small: I was not a member of it, but I did work with individuals who were.

Burton-Rose: After you moved to Oakland you began treating several highprofile jailed and incarcerated Black liberation activists.

14 The Hospital Survey and Construction Act - also known as the Hill-Burton Act after the sponsoring senators - was passed in 1946. The initial law prohibited institutions that received funding from discriminating based on race, color, national origin, or creed, while permitting "separate but equal" institutions (i.e., hospitals that refused treatment to African Americans and other people considered "colored"). The "separate but equal" provision was challenged successfully in Simkins v. Cone (323 F.2d 959, 1963), on which see Nelson 2011: 23-24, 39-42.

15 The museum is currently called the Charles H. Wright Museum of African American History. See the museum website: https://www.thewright.org/. On Charles H. Wright (1918-2002), see McLellan 2002.

16 Philip Hart served as a senator for Michigan from 1959 to 1976 . His obituary in the New York Times noted that he "played a large although not always visible role in shaping almost every major civil rights, consumer and antitrust bill passed by Congress since the early 196os." Madden 1976, D11.

Silas Norman Jr. (1940/1941-2015), on whom see McManus 2015. 
Small: Angela Davis was my patient for over thirty years. I visited her twice a week when she was in jail in Marin County, and once a week in Santa Clara.

One of her colleagues asked me to go visit her. He gave her name to one of my attorneys. So I went out to visit her, and the guards at the jail said, "No, you can't visit her." The late Sheldon Otis came out; he gave them hell. ${ }^{18}$ Davis's attorneys sent me up, so then they got a court order for me to visit her. I used to drive over there, every Wednesday afternoon, right before I went to the George Jackson Free Clinic, Friday mornings. This was prior to the HIPAA rules, where you're not supposed to share people's medical evidence. ${ }^{19}$ Whenever I would go in to see her, the next day I would get a note - a complaint from the sheriff - saying that I discussed this, I discussed that. They would actually have the guard go to the cell next to the cell I was in and have an ear to the wall and listen to everything we were saying.

When Angela Davis was transferred to Santa Clara, they asked me to meet with a Dr. Lee. ${ }^{20}$ Dr. Lee was the founder of the Palo Alto Clinic. He was an elderly, paternalistic person. The county public health officer and the chairman of gynecology at the Santa Clara Valley Hospital told me that they did not want me to be Angela's doctor. They told me Dr. Lee was going to be the doctor and that I should go talk to him for a passing of the guard. I rode down there. I wasn't that anxious to talk to Dr. Lee so I was about an hour late when I got there. He said: "One thing I never did was keep another physician waiting."

Angela Davis couldn't stand him. I told Angela: "Look, if you want me to be your doctor, you have to complain." Well, Angela raised hell, and so they called me back: "Will you please come back?" I used to go down there once a day. Apparently, the people were nicer to her at Santa Clara because Angela told me that when they were driving her back and forth they would let her get out of the car and exercise and walk a little. Frank Lloyd Wright designed the county courthouse in Marin County, and so the jail is actually a very artistic building, with the courthouse and all of that. ${ }^{21}$

18 On Otis, see Woo 2002.

19 The Health Insurance Portability and Accountability Act passed into law on August 21, 1996.

$20 \quad$ Russell Lee (1895-1982). For an obituary see Altman 1982.

21 Small is referring to the Marin County Civic Center, which opened in 196o and houses the Marin County Superior Court. In August of 1970, seventeen-year-old Jonathan Jackson, younger brother of the incarcerated Black Panther and "Soledad Brother" George Jackson, attempted to free his brother and his brother's codefendants. A bloody shootout ensued, with four people killed, including the judge in the case. Davis was tied to one of the guns used by Jonathan Jackson. Fearing that she could not receive a fair trial in a politically and racial charged environment, Davis fled rather than face arrest. She became number one on the FBI's Most Wanted list before being captured on October 13. A high-profile trial 
After I had visited Angela two or three times she told me that I needed to go visit George Jackson. Then I was over in Huey's penthouse and he told me that George was a legendary person and that he had medical problems and I should go visit him. The Panther attorneys got a court order; the only reason I got to see Angela Davis was because of a court order.

I went over there. A guard who was a member of the John Birch Society searched my little black bag and they had George in a cage. San Quentin is such an ancient prison. We walked into this room. There was a desk in there and about ten guards standing all around. I gave him a physical. George told me how he could do a thousand push-ups a day and do a hundred on his head. I asked him, how did he do that, and he got up against the wall and started going up and down. It was incredible.

I guess they had all those guards around us for security reasons but after that - the other two visits - they didn't have it. "Red" Nelson got the judge to revoke the court order because he said I was a security risk. ${ }^{22}$

Burton-Rose: How did you react to news of George's death?

Small: We were very sad. I was driving back with my cousin from Half Moon Bay and I heard it on the radio. The first thing I did, I drove by Ms. Jackson's house. Cecil Williams was there. ${ }^{23}$ Ms. Jackson told me that she heard it on the radio and she called up the prison. The person who answered the phone said: "We killed one of your sons last year and we just killed another one of your sons. Pretty soon you won't have any more sons left!" That's how she found out about it.

I stayed up till about three o'clock in the morning. Cecil Williams stayed up with her too. Losing two sons like that ...

Burton-Rose: Before you went to China, what were your associations with China? I see you have a book on Paul Robeson on the shelf behind you. Were

ensued; after sparking an international campaign demanding Davis's freedom, it ended in her acquittal. For Davis's account of her flight, see Davis (1974) 1988. On the stakes of Davis's trial, see Davis et al. 1971 .

22 Louis Sander "Red" Nelson (d. 2001), on whom see Hatfield 2001. For a more detailed recounting of his first visit with Jackson, see Small 2015. In this article, Small explained that Jackson identified to him the San Quentin guards who belonged to the white supremacist John Birch Society.

23 Cecil Williams (b. 1929) is the pastor emeritus of Glide Memorial United Methodist Church in San Francisco. 
you aware of W.E.B. Du Bois, Paul Robeson, and other internationalist African American activists who had traveled there?

Small: They had a picture of Du Bois at the Peking University museum; apparently, he met Mao in China.

Burton-Rose: Yes, in 1959, more than a decade before the first Panther delegation. ${ }^{24}$ How did your trip to China come about?

Small: I would not have gone to China except for the Black Panthers. In 1971 Huey Newton went to China with Elaine Brown and Robert Bay, and they spent some time with Zhou Enlai. ${ }^{25}$ They offered to give Huey political asylum there but Huey didn't want it. Huey asked Zhou Enlai if they could send a Panther delegation. David Hilliard called me into his office. He had a map of the world behind him. He asked me if I wanted to go to China. ${ }^{26}$ I said: "That sounds like a good idea." I jumped at the chance.

We were supposed to go shortly before Nixon's trip, but the American government wouldn't let Masai ${ }^{27}$ and Elaine Brown go across the border to Canada to get the visas. They were afraid we'd be over at the same time as Nixon. ${ }^{28}$ They could only get to Montreal to get the visas after Nixon had come back. ${ }^{29}$ We wound up going shortly after Nixon came back.

Burton-Rose: Did you fly into Hong Kong or did you go directly over?

24 Du Bois visited China three times: in 1936, 1959, and 1962. During the 1959 and 1962 visits, he was accompanied by his wife, Shirley Graham DuBois. For a contemporaneous account of the 1959 visit, see Central News and Documentary Films Studio 1959. Among the recent profusion of scholarship on Du Bois in China, see Johnson 2013, 238-42; Frazier 2015, 36-71; Brown 2016.

25 On this encounter - and the iconic photograph it produced - see Huang 2018.

26 Hilliard mentions Small twice in his autobiography but does not discuss the China delegation: Hilliard 1993, 309-10, 339-40.

27 Raymond "Masai" Hewitt (1941-88), who held the position of minister of education in the Black Panther Party at this time.

28 Nixon visited February 21-28, 1972. It was the first visit of a United States president to the People's Republic of China and laid the groundwork for full resumption of diplomatic relations in 1979 .

29 Brown visited China twice: the first time with Eldridge Cleaver in 1970, then the next year with Huey Newton. She describes these trips in Brown 1992, 231-32 and 295-304, respectively. Brown described the process of traveling to Montreal with Hewitt to meet with the staff of the Chinese embassy in order to plan the first Panther delegation to China. As far as Small is aware, the 1972 delegation in which he participated was preceded by a similar trip to Montreal by Brown. 
Small: We flew into Vancouver. And apparently the American government the CIA - had the Canadian government put us all in a room. They were going to call each of us up individually, talk to us about terrorism. Allan Brotsky, ${ }^{30}$ Charles Garry's law partner, was there; he threatened to sue the airlines. So they said: "Okay, we'll fly you back to Seattle, and you can fly to China [via] Hong Kong from Seattle." Apparently, Hong Kong had a rule that you couldn't land after twelve o'clock. So they flew us to Japan and they put us up at this fancy Hilton Hotel overnight, and then they took us to Hong Kong. Wherever we were going, there would be crazy newspapers, tabloids all over us. "Are you going to China?" "Where are you going?" Blah blah blah ... ${ }^{31}$ When we arrived in Hong Kong there was an English [language] newspaper that said Angela Davis was thought to be on the trip because I was her doctor. Obviously she wasn't on the trip.

Burton-Rose: That was a very circuitous route: you went from Vancouver to Seattle to...?

Small: Tokyo. Then we spent the night at a hotel the Chinese had an interest in, and they took us across by train and we spent the night at Canton. Then they took us to Beijing. We stayed at the Peking Hotel. At the time, it may have been the only hotel in Peking. But we were guests of the Chinese government. We went to Yenan [Yan'an], ${ }^{32}$ visited the caves that Mao lived in when he was there, met some of the peasants who had been with Mao; went to Nanking, we visited Sun Yat-sen's grave; we went to Shanghai, saw the place where the first Communist Party was founded. That's how we got interested in acupuncture.

In Shanghai, there was a bridge between the European section and the Chinese section, and they had a sign that said: "No dogs, no Chinese allowed." They may still have it. ${ }^{33} \mathrm{I}$ have a sign I used to have at my office at the Harriet

30 Allan Brotsky (1920-2015) was a partner in the firm Garry, Dreyfus, McTernan, and Brotsky, established in 1967 .

31 For an example of coverage of the Panther delegation in the (non-Black Panther Party) African American press, see "Panthers, Others Off to Red China" 1972.

32 We have retained the Wade-Giles transcriptions for some Chinese-language terms provided by Small because it is clear from his pronunciation that these are the forms with which he is familiar.

33 This sign was not historically accurate as presented at the time of the Panther delegation. For how this nonhistorical sign became a historical actor in and of itself, see Bickers and Wasserstrom 1995 . 
Tubman Clinic; for thirty-six years, we had it hammered up: "No dogs, Negros, or Mexicans." 34

Burton-Rose: Regarding your interest in acupuncture, the first time that you saw it performed was in Shanghai?

Small: We saw operations in Peking; someone's being operated on, and he's there talking while being operated on. I realized there's something in it. I had a slight stiffness in my neck, so I said that I wanted to have acupuncture. They did that to me. I felt the numbness shooting up the side of my head.

The Chinese wanted us to learn how to do it right. When I went to Shanghai, $\mathrm{Dr}$. Wu, who was a professor at the Chinese Traditional Medical school, came in and gave us a couple of comprehensive lectures on acupuncture. I taped those lectures. I only taped the English; I didn't tape the Chinese, which would've made more sense.

When I came back to the Bay Area, there was a well-known photojournalist, David Bacon. David approached me at the George Jackson Free Clinic. He had this book called Basic Acupuncture Techniques translated; brilliant book. And he had me write the introduction to it. We used to meet at the West Oakland health center, doing the points on ourselves. Alex Feng and I, we liked to prep with doctors by doing the points on each other. We did all the points on ourselves; at least, I did all the points on myself.

I used to do house calls in West Oakland, doing acupuncture on poor people and Medi-Cal ${ }^{35}$ patients, when acupuncture was not legal in the state. ${ }^{36}$ People could only do it as research. I had someone in Mexico make some cards for me that said, "Tolbert Small, Research Acupuncturist."37 And then when I went back to my residency, 1974-76, I did acupuncture in the clinic there. I did acupuncture on my wife during labor; ${ }^{38}$ we did it during the birth of two of my children. I was probably one of the first doctors in the United States to do acupuncture on someone in labor.

34 For a broader perspective on American racist memorabilia as a pedagogical tool, see Pilgrim 2015.

35 Medi-Cal is a public health insurance program for low-income Californians, administered by the California Department of Health Care Services.

36 In 1974 acupuncturist Miriam Lee was arrested for practicing medicine without a license. Her patients protested strenuously at her trial, testifying to Lee's ability. In response, Governor Ronald Reagan declared acupuncture legal as an experimental procedure. In 1976 Governor Jerry Brown officially legalized acupuncture in California.

37 Reproduced as figure 11 in Meng 2021a, 288.

38 Reproduced as figure 12 in Meng 2021a, 289 . 
Burton-Rose: You observed acupuncture anesthesia in China, but in using acupuncture in childbirth you were innovating?

Small: I tried to do everything scientifically. I looked up several articles on acupuncture and childbirth and I used those points.

I subscribed to the Journal of Chinese Medicine. It was an English-language journal with a green cover. It was mailed to me from mainland China. I used to get that and China Reconstructs. I got that for about twenty or thirty years. I stopped getting it when they put in China Reconstructs that they decided to let millionaires become members of the Communist Party. I said: "Well, maybe it's time not to renew my subscription."

Burton-Rose: You mentioned that acupuncture was illegal when you first started practicing. Was the arrest and trial of Miriam Lee, in 1974, on your radar? 39

Small: Outside of Asian communities, acupuncture was not around. Even in China at that time, it was something that was done for the underclass, not the elite. When we were over there it was a mix of traditional medicine and Western medicine; they did an excellent job. But Mao's doctor [Li Zhisui] writes in his book that Mao never practiced traditional medicine; he only used Western medicine. ${ }^{40}$

What happened in California was that people put pressure on Jerry Brown to pass [an acupuncture legalization bill], and Jerry Brown, being a liberal democratic voice, fortunately signed the bill. That made it legal. In fact, Alex who does acupuncture with me - I wrote a letter for him and he actually got on the acupuncture licensing board.

When we closed the [Tubman Clinic] office in 2016, I worked at Hill Physicians - one of the large HMO s [health maintenance organization] here because they promised to employ all my employees. Then I wanted to get back into the community, so I worked the last three years at the Native American Health Clinic. They asked me for an acupuncture certificate. Of course, when I started out there were no schools for acupuncture: it was illegal. I just had my previous employer call them up and inform them that I was the first acupuncturist in Hill Physicians.

39 For Lee, see footnote 36. A laudatory account of Lee is Fan and Fan 2014.

40 Li Zhisui served as Mao's personal physician from 1954 until Mao's death in 1976. See Li 1994, 84 . 
Burton-Rose: Legally, you were grandfathered in?

Small: I do it under my MD, as a licensed medical doctor. Because my theories about how it works, it's a little different from the theories that all the traditional Chinese schools [use]. There's so much politics involved. I heard that when they did license acupuncture in California, part of the license was that no one from China could come over here and practice, licensed. And then at one time, they wanted to make it only acupuncture schools; medical doctors couldn't do it. It's all about money.

It's ironic now because it's difficult for poor people to get acupuncture. Acupuncture can be kind of a yuppie thing. Marty Lynch of the Lifelong community clinic, ${ }^{41}$ they sued the state to make Medi-Cal to pay for acupuncture. Medi-Cal paid for it, but they said you can only have two treatments a month. And then the reimbursement was so low that most of the acupuncturists probably couldn't pay their rent; it was like twelve or fourteen dollars. It was just a scam, like the whole Medi-Cal thing is a scam, because they paid the doctors so little that most doctors don't see Medi-Cal patients. Those patients wind up going to community clinics.

Twenty-five percent of our population at the Harriet Tubman Clinic was on Medi-Cal; we served the needs of the community for thirty-six years, from 1980 to 2006. We had about twenty-three patients who were physicians. We had professors, we had attorneys, we had a judge, we had Congresspeople, and we had 25 percent Medi-Cal patients. It would be interesting to see the Medi-Cal patients come off their buses and go there, and seeing the other patients come in with their Lexuses and Mercedes [laughs].

Burton-Rose: That speaks well of the clinic; you want a practice that cuts across social divisions.

Small: Yeah, we were in a working-class neighborhood. It was in a Victorian house on Foothill [Avenue], eight blocks from Lake Merritt.

Burton-Rose: In your 1974 articles on acupuncture you mentioned that you had also observed veterinary acupuncture while in China. Is that correct?

Small: I read about veterinary acupuncture but I actually never saw it. I was told that they were doing it on animals. When I first came back, I gave a talk to

41 Lifelong Medical Care. See: https://www.lifelongmedical.org/about-us/executive -leadership. 
a bunch of doctors, and I had them do Hoku on themselves. ${ }^{42}$ They all felt the numbness, then they all told me that the reason acupuncture worked in China was because the Chinese were stoic. So I would show them this horse being operated on. It's like [sarcastic]: "The horse is stoic, that's why he could tolerate the acupuncture." It's like what they said about [J. Marion] Sims, the father of American gynecology. ${ }^{43} \mathrm{He}$ did surgery on slaves. He felt that Black folks could not feel pain like white folks do. That's why sometimes when Black folks go into the emergency room, they tell them: "You're not in pain."

Burton-Rose: If the first use of acupuncture that you were exposed to was anesthesia, what other sorts of uses did you put acupuncture to over the course of your practice?

Small: I mostly used it for pain. Occasionally I would do someone with asthma, but we dealt with a lot of pain, and I created this protocol for back pain. In some of my early cases I used it a lot for pain. I did the Lung point several times on a heroin addict, and it helped him. Apparently Mutulu Shakur went to Canada and learned how to do acupuncture. At Lincoln Hospital [in the Bronx in the 1970s], they brought in acupuncture. ${ }^{44}$ It's ironic: they started the five-point program which is being used in a thousand clinics throughout the world - it's being used especially in England ${ }^{45}$ — and he's still in prison. He served his thirty years, but they won't let him out on parole. ${ }^{46} \mathrm{He}$ always signed his letters "stiff resistance," so they said he isn't sorry. He had one thirty-year

42 Hegu 合谷, or Large Intestine 4. The lecture to which Small refers occurred in 1991 at Summit Hospital in Oakland. The transcript of his lecture is preserved in his archives under the title "Traditions of Healing: Acupuncture." The lecture slides, shared by Small with Burton-Rose and $\mathrm{Wu}$, include a photograph from an English language periodical the early 1970s with a caption reading: "Veterinary surgeons of the Peking Municipal Veterinary Hospital perform an abdominal operation on a mule with acupuncture anesthesia manipulated by electricity." A search of China Reconstructs for the relevant period did not reveal the source of this article.

43 On Sims, see Holland 2018. On April 17, 2018, Sims's statue was removed from Central Park, where it had stood across from the New York Academy of Medicine.

44 On the Lincoln Hospital Detox program in the Bronx in the 1970s, see Khazan 2018 and Shakur's source letter for that article, Shakur 2018, as well as the more derogatory Burrough 2015, 448-53, 465-70. A laudatory account is Donovan 2020.

45 On the five-point protocol, see Meng 2020b.

46 Shakur received his eighth denial from the US Parole Commission in May 2018. For details see Family and Friends of Dr. Mutulu Shakur 2018. 
sentence on him, thirty years, and the lady who shot Gerald Ford had thirty years, but they won't let him out of jail. ${ }^{47}$

He's got multiple myeloma, which the average life span of living is three years. They tell him he's going to live for eight years; I don't think he has that much time left.

Wu: Dr. Small, while we're on the topic of Mutulu, I'm curious about the way in which acupuncture knowledge spread through the community. You went to China with the Black Panthers, you witnessed acupuncture anesthesia, and when you came back, you wrote these articles. Were you also telling people about this? I'm wondering how Mutulu got specifically interested. He went to Canada to do some training too?

Small: Yeah, he went to Canada, learned how to acupuncture. He said some of his children became ill and had acupuncture, realized how it worked, and that's why he went to Canada.

I was actually supposed to go to New York [in 1975]. I was in bed with the flu, temperature 104, so I never got the chance to meet the Panthers in New York. Although I did meet some of them on the West Coast.

Burton-Rose: That's also the time period when there was an East Coast-West Coast split within the Panthers. Did that divide impact your awareness of what was happening with the Lincoln Detox clinic when you were in Berkeley and Oakland?

Small: Yeah, there was an East-West problem, but not about acupuncture.

Burton-Rose: When do you first remember hearing about the Lincoln Detox program?

Small: It was probably sometime in the late ' 70 . I had read an article, in 1973, about two neurosurgeons in Hong Kong who were doing acupuncture. ${ }^{48}$ They noticed, they used the Lung point [in the ear]. When they did auricular

47 There were actually two white women who attempted to assassinate President Gerald Ford in California in 1975; both served over thirty years, then were paroled. Manson family cultist Lynette Alice "Squeaky" Fromme made her attempt in Sacramento on September 5 , 1975. She was paroled August 14, 2009. On September 22, 1975, in San Francisco, Sara Jane Moore took two shots at Ford. She was released on parole on December 31, 2007.

48 The original article is Wen and Cheung 1973. Small could also be referring to an article summarizing the findings of Wen and Cheung: "Hong Kong Doctors Use Acupuncture 
acupuncture, the drug addicts used less methadone. That was the first, when I heard about it.

The way acupuncture got started, in 1958, they were doing breast biopsies with acupuncture, turning the needles, but then they decided that they can't be turning the damn needles during the entire surgery. That's when they developed electrical acupuncture. I found I used mostly electrical acupuncture. It takes a lot longer to do, but it works better for pain relief.

Burton-Rose: The older method would just be that the doctor does qigong or taiji [tai chi] and runs the circuit himself.

Small: A lot of people, they still do the older method. But let's face it, if you're doing acupuncture, and you're doing it on twenty people, you can't be stimulating all of them. You just do the needle points, and you can actually put the seeds or something in the ear, and have the people massage them themselves.

I used to spend forty-five minutes with each patient, at least, stimulating with the electrical acupuncture. They told me in China that it takes fifteen minutes before it starts to work, so I figured I needed to do it for at least thirty minutes, and I'd always do it for an extra fifteen minutes. Electrical acupuncture, [it] is not practical doing that if you've got twenty drug addicts in a room.

Burton-Rose: One of the stereotypes about acupuncture is that an acupuncturist will listen to your problems, and a Western doctor wants to just treat your body. It sounds like you listened to your patients as a primarily biomedical practitioner.

Small:Well, that's true. I used to do a lot of interviewing of people. I interviewed my grandparents, talked about slavery. I interviewed my patients, talked about [their lives] during World War I and World War II.

The Western midwives spend more time with their patients than medical doctors, and medical doctors are trained to treat diseases and they're not so much trained to prevent diseases. Pills and shots, and they operate on you.

Burton-Rose: Where did you even get needles in 1972 and ' 73 ?

to Relieve Addicts' Withdrawal Symptoms" 1973. Wen and Cheung employed electrical acupuncture. 
Small: I brought some needles back from China. Then, even though it was illegal to go to China, I had friends who would go there, and I would have them bring back needles, bring back [electrical] acupuncture [machines].

Burton-Rose: What kind of broad shifts have you seen in terms of the receptivity of patients to traditional Chinese medical practices, and the relationship between acupuncture and social justice more particularly?

Small: When I was doing acupuncture, they were mostly poor patients and Medi-Cal patients. And I explained it to them. Eana [Meng] told me that she sees all these upper-class people walking around with needles and beads in their ears. ${ }^{49}$ In this country some of the acupuncturists charge a hundred dollars for a treatment, for people who can afford to get it. Although, ironically, it was designed in China to take care of the masses, [whereas in the United States it has] become something for the privileged.

Burton-Rose: Do you see any efforts to make acupuncture more widely available, beyond elite patients?

Small: Marty Lynch - who just resigned [after being] the head of the Lifelong [clinic] for thirty years - told me they were gonna sue the state, make them pay for more than two visits. But it still wouldn't work because if the state gives someone twelve or fourteen dollars for a treatment, how can [the practitioners] afford to do it? What some [practitioners] do [is] a group treatment, and they have discounted, discounted fees.

Burton-Rose: Right: multiple patients at the same time, in order to make it more economically feasible.

Small: But you know, racism plays a factor in the fact that we're probably the only "Western country" that doesn't have national medicine. You know what happened was Lyndon Johnson said: "If you have a poor white person who doesn't have a cent in his pocket, tell him that he's better than the $\mathrm{n}-\mathrm{s}$, and he'll be happy."50 And so, they feel that if you have socialized medicine, all those poor Black folks will get it, so we can't have it.

49 Meng (of Harvard University) is one of the researchers helping Small preserve his archives. Meng 2021b.

$5^{\circ}$ Bill Moyers, who worked as a staffer for Johnson in 196o, recalled the future president explaining to him: "If you can convince the lowest white man he's better than the best 
Wu: I have a question going back to your use of acupuncture. You said you treated a lot of people for pain. What kind of pain were the people who came to you dealing with?

Small: Osteoarthritis, arthritis of the back, herniated disc, neuropathies.... You would do Hoku here [indicates LI-4 point between thumb and index finger], and for a tension headache I would do it on my mother-in-law, and her headache went right away. And you try to think of how that works. Turns out that the trigeminal nerve is connected to the medial meniscus, the spinal cord. The Chinese had proved that there were inhibitory blockages in certain areas of the brain, like the thalamus in midbrain, that they had proven that you could block, in the spinal cord, the areas of the inhibitory synapses. ${ }^{51}$ And later, after I wrote this paper, I found out that acupuncture increases endorphins, which can lower your blood pressure.

Burton-Rose: You've been very involved in sickle cell anemia as an illness that particularly impacted the African American community and was ignored by the white establishment for that reason. Was there anything that you found acupuncture to be particularly good for that was specific to an underserved community? For example, hypo- or hypertension?

Small: They say acupuncture works for hypertension - it increases bradykinin, a vasodilator - but only as long as the blood pressure does not last a long time. When I do acupuncture for pain, one treatment will give them relief for anywhere from three to five days. You need a series of treatments.

There's a talk I gave in 1991 [in which I said]: "The ghetto's healthcare mirrors the institutional racism in our society." As national chairman of the Black Panther Party's Sickle Cell Anemia Foundation, we dramatized the American government's neglect of sickle cell anemia. These were the times in which American institutions raised annually 7.9 million dollars for muscular dystrophy, 1.9 million dollars for cystic fibrosis, and a mere hundred thousand dollars for sickle cell anemia. ${ }^{22}$ Sickle cell anemia has a greater morbidity and

colored man, he won't notice you're picking his pocket. Hell, give him somebody to look down on, and he'll empty his pockets for you" (Moyers 1988). On the way in which Johnson's intense racism coexisted with his championing of civil rights legislation, see Serwer 2014.

51 For the English-language works on acupuncture anesthesia in China that Small consulted in the early 1970s, see Small 1974a, 87; Small 1974b, 161-62.

$5^{2}$ These figures come from Scott 1970. This article and its impact is discussed in Nelson 2011, 119-25. 
mortality than both muscular dystrophy and cystic fibrosis. Sickle cell anemia is a disease predominantly found in the Black community. Actually, the Black Panther Party's free clinics provided testing and consultation to hundreds of thousands of Black patients of sickle cell anemia. Our dramatization of the neglect of sickle cell anemia forced President Nixon's espousal of a program to reverse the country's neglect of sickle cell anemia. The late Bert Lubin, and Elliott Vichinsky, sickle cell czar at Children's Hospital, said they weren't able to get any money until the Black Panthers [drew attention to the issue]. ${ }^{53}$

Last time I talked to them the government was cutting down their money for sickle cell anemia. Because now, with the gene research, there's been at least one case where they've actually cured sickle cell anemia by CRISPR, ${ }^{54}$ where they actually can reshape the genes. 'Cause what happened with sickle cell anemia is glutamic acid is replacing valine on the DNA chain and changes the charges on the hemoglobin so the cell sickles. People have very exquisite pain; used to be people would be dead by the time they were thirty-five or forty. I had about thirteen or fourteen sickle cell patients when I was in practice. And they would sometimes go into emergency rooms and people wouldn't - this was before they were giving everybody narcotics - people would not treat their pain seriously.

Burton-Rose: How has your idea of China changed since your visit?

Small: We were young and idealistic. We believed that health care was a right for the people; that in China at that time health care was a right, education was a right. We all felt that it was a government that served the needs of the people, rather than a government that served the needs of corporations and the wealthy, which most governments do. We were very enthused about that.

I joke that China has gone from "Serve the People" to "Serve Coca-Cola."

Wu: Dr. Small, when you look over the long arc of history - and you've seen so much - the needs that you fought for back in the '7os are still with us today. What is your sense of where we need to go?

Small: It's not a hundred-yard dash; it's a long-distance marathon. Our grandchildren will probably be trying to make this a better world. But the consciousness of the American people has been raised. You see all the diverse people

53 On Lubin, see Kelly 2020. For Vichinsky's comments on Small's legacy, see Burt 2006.

54 Clustered Regularly Interspaced Short Palindromic Repeats, on which see the account in Plater 202O. 
walking around saying, "Black Lives Matter"; most of them are not Black. The opposition says, "All Lives Matter," but if all lives mattered Emmett Till would still be alive today. 55

There are going to be people who want governments to provide education, health care, child care, and there are going to be people who want the governments to make money for them and their friends. It's going to be a longdistance race.

All these community free clinics sprang up in the early '70s. Most of them became very large community clinics that get money from the federal government. The Panther clinics in Portland and Seattle, they're still in existence but they survived by becoming government-funded community clinics.

What I see is hope in the young people, like Bernie Lim. ${ }^{56}$ She's a medical student. She has this pop-up free clinic that goes into poor neighborhoods. There's hope in the youth and the fact that you've got all these people - most of them non-Black - walking for Black Lives Matter. It's pivotal that they can be organized.

\section{Acknowledgments}

The interviewers are grateful to Colin Garon for providing the initial transcription of the first interview session. We also wish to thank David Bacon for sharing his recollection of practicing acupuncture with Small in the early 1970 and Eana Meng for providing feedback and corrections.

55 In 1955 Emmett Till (1941-55), a fourteen-year-old African American boy from Chicago, was kidnapped, tortured, and murdered by two white men while visiting Mississippi. The perpetrators believed that Till had made advances toward Carolyn Bryant, a white woman. After receiving her son's mutilated corpse, Till's mother Mamie Elizabeth Till-Mobley (1921-2003) insisted on an open-casket funeral because "I wanted the world to see what they did to my baby." Mass attendance at the funeral and the accompanying media coverage combined to make Till's death a catalyzing moment in the Civil Rights Movement. Bryant later admitted lying in her testimony about Till. See Tyson 2017.

$5^{6}$ Bernadette Lim runs the Freedom Community Clinic. According to its website, the Clinic provides "community-centered healing that integrates ancestral, indigenous, and holistic practices with the strengths of Western medicine." It continues: "All services are offered for free and/or at sliding scale to our communities in the Bay Area, especially Black, Indigenous, and POC communities." For further details see the organization's website: https://www.freedomcommunityclinic.org/. 


\section{About the Interviewers}

Daniel Burton-Rose is a visiting assistant professor in the Department of History at Wake Forest University, North Carolina. Before completing his doctorate in East Asian studies at Princeton University in 2016, he authored Guerrilla USA:The George Jackson Brigade and the Anti-Capitalist Underground of the $1970 s$ (University of California Press, 2010) and edited the accompanying primary source collection Creating a Movement with Teeth: A Documentary History of the George Jackson Brigade (PM Press, 2010). He is the East Asia Area Editor of Asian Medicine.

Yi-Li Wu is an associate professor of women's and gender studies and history at the University of Michigan, Ann Arbor. She is the author of Reproducing Women: Medicine, Metaphor, and Childbirth in Late Imperial China (University of California Press, 2010) and is completing a manuscript on the history of medicine for injuries in China. She is the Senior Editor of Asian Medicine.

\section{Bibliography}

Altman, Lawrence K. 1982. "Dr. Russell Lee, 86, Physician; A Pioneer in Group Practice." New York Times, January 29, 1982, sec. B, p. 4. https://www.nytimes.com/1982/o1/29/ obituaries/dr-russell-lee-86-physician-a-pioneer-in-group-practice.html.

American Association of Acupuncture and Oriental Medicine, National Certification Commission for Acupuncture and Oriental Medicine, Council of Colleges for Acupuncture and Oriental Medicine, and the Accreditation Commission for Acupuncture and Oriental Medicine. 2007. AOM Pioneers \& Leaders 1982-2007: A Commemorative Book of Challenge and Courage, vol. ı. N.p. https://www.aaaomonline .org/resources/Pictures/Pioneers\%2oand\%2oLeaders\%2oVol\%2o1.pdf.

Andrews, Bridie. 2014. The Making of Modern Chinese Medicine, 1850-1960. Vancouver: University of British Columbia Press.

Bickers, Robert A., and Jeffrey N. Wasserstrom. 1995. "Shanghai's 'Dogs and Chinese Not Admitted' Sign: Legend, History and Contemporary Symbol." China Quarterly 142: 444-66.

"Black Panther Party Members on Way to China." 1972. Los Angeles Times, March 6, $1972,2$.

Brown, Elaine. 1992. A Taste of Power: A Black Woman's Story. New York: Pantheon Books. 
Brown, Keisha A. 2016. "Blackness in Exile: W.E.B. Du Bois' Role in the Formation of Representations of Blackness as Conceptualized by the Chinese Communist Party (CCP)." Phylon 53, no. 2: 20-33.

Burrough, Bryan. 2015. Days of Rage: America's Radical Underground, the FBI, and the Forgotten Age of Revolutionary Violence. New York: Penguin Press.

Burt, Cecily. 2006. "No Small Contribution: Doctor Helped Community." East Bay Times, October 5, 2006. https://www.eastbaytimes.com/2006/10/05/no-small-contri bution-doctor-helped-community/.

Carson, Clayborne. 1981. In Struggle: SNCC and the Black Awakening of the 196os. Cambridge, MA: Harvard University Press.

Central News and Documentary Films Studio. 1959. "Welcome W.E.B. Du Bois!" Documentary short. Digitally archived: https://credo.library.umass.edu/view/full/ mums312-b246-ioo2.

Dandridge, Tenisha. 2020. "The Unusual Tale of Acupuncture, Racism, and African American History in the USA." DAO Labs, June 9, 2020. https://mydaolabs.com/ blogs/the-way/acupuncture-racism.

Davis, Angela Y. (1974) 1988. Angela Davis: An Autobiography. New York: International Publishers.

Davis, Angela Y. 1971. Bettina Aptheker and other members of the National United Committee to Free Angela Davis and all Political Prisoners, eds. If They Come in the Morning: Voices of Resistance. New York: Third Press.

Dittmer, John. 20o9. The Good Doctors: The Medical Committee for Human Rights and the Politics of Health Care in America. New York: Bloomsbury Press.

Donovan, Mia, dir. 2020. Dope is Death. Documentary. 82 minutes. Montreal, Canada: EyeSteelFilm.

“Dr. Tolbert Small: Journey of a People's Doctor." 2002. Revolutionary Worker 1139, February 17, 2002. http://the-peoples-doctor.com/archives/dr-tolbert-small-journey -of-a-peoples-doctor/.

Editorial Committee for Acupuncture and Moxibustion of the People's Health Publishing House, Peking. Basic Acupuncture Techniques. Translated by Lee Hsu. San Francisco, CA: Basic Medicine Books, 1973.

Family and Friends of Dr. Mutulu Shakur. 2018 "Federal Lawsuit Against the Parole Commission and Bureau of Prisons." Mutulu Shakur, September 29, 2018. http:// mutulushakur.com/site/2018/og/federal-lawsuit-parole-denials/.

Fan, Arthur Yin, and Ziyi Fan. 2014. "Miriam Lee: A Heroine for the Start of Acupuncture as a Profession in the State of California." Journal of Chinese Integrative Medicine 12, no. 3: 182-86.

Fang, Xiaoping. 2012. Barefoot Doctors and Western Medicine in China. Rochester, NY: University of Rochester Press. 
Frazier, Robeson Taj. 2015. The East Is Black: Cold War China in the Black Radical Imagination. Durham, NC: Duke University Press.

Hatfield, Larry D. 2001. "'Red' Nelson, San Quentin Ex-Warden." San Francisco Chronicle, June 19, 2001. https://www.sfgate.com/news/article/Red-Nelson-San-Quentin -ex-warden-29o8181.php.

Hilliard, David. 1993. This Side of Glory: The Autobiography of David Hilliard and the Story of the Black Panther Party. Boston: Little, Brown.

Holland, Brynn. 2018. “The 'Father of Modern Gynecology' Performed Shocking Experiments on Enslaved Women." Sky History, August 29, 2017, updated December 4, 2018. https://www.history.com/news/the-father-of-modern-gynecology-performed -shocking-experiments-on-slaves.

“Hong Kong Doctors Use Acupuncture to Relieve Addicts' Withdrawal Symptoms." 1973. New York Times, April 5, 1973. https://www.nytimes.com/1973/o4/o5/archives/ hong-kong-doctors-use-acupuncture-to-relieve-addicts-withdrawal.html.

Hsin, Yu-Ling. 1973. “Acupuncture Anesthesia with One Needle.” China Reconstructs 22, no. 3: 18-20.

Huang, Mingwei. 2018. “Between Men': Vying Masculinities in 1970s U.S.-China Relations." The Scholar \& Feminist Online 14, no. 3. http://sfonline.barnard.edu/ feminist-and-queer-afro-asian-formations/between-men-vying-masculinities-in -1970s-u-s-china-relations/.

Jeffries, Hasan Kwame. 2009. Bloody Lowndes: Civil Rights and Black Power in Alabama's Black Belt. New York: New York University Press.

Johnson, Matthew D. 2013. "From Peace to the Panthers: PRC Engagement with African-American Transnational Networks, 1949-1979." Past and Present 218: 233-57.

Kelly, George. 2020. "Ex-UCSF Benioff Children's Hospital CEO Bert Lubin dies at 81." East Bay Times, June 30, 2020. https://www.eastbaytimes.com/2020/06/30/ ex-ucsf-benioff-childrens-hospital-ceo-bert-lubin-dies-at-81/.

Khazan, Olga. 2018. "How Racism Gave Rise to Acupuncture for Addiction Treatment." The Atlantic, August 3, 2018. https://www.theatlantic.com/health/archive/2018/o8/ acupuncture-heroin-addiction/566393/.

Lei, Sean Hsiang-lin. 2014. Neither Donkey nor Horse: Medicine in the Struggle Over China's Modernity. Chicago: University of Chicago Press.

Li, Zhisui. 1994. The Private Life of Chairman Mao: The Memoirs of Mao's Personal Physician. With Anne Thurston. Translated by Tao Hung-chao. New York: Random House.

Madden, Richard L. 1976. "Senator Philip A. Hart Dies at 64; Was Called 'Conscience of Senate.” New York Times, December 27, 1976, D11.

McLellan, Dennis. 2002. "C. Wright, 83; Father of Black Museums." Los Angeles Times, March 12, 2002. https://www.latimes.com/archives/la-xpm-2002-mar-12-me 
-wright12-story.html\#: :text=Wright\%2C\%2oa\%2oDetroit\%2oobstetrician\%2O and,the\%2oDetroit\%2osuburb\%20of\%2oSouthfield.

McManus, Tracey. 2015. "Civil Rights Activist, Former Paine College Chairman Silas Norman Jr. Dies at 74." Augusta Chronicle, July 20, 2015. https://www.augustachroni cle.com/article/20150720/NEWS/307209899.

Meng, Eana. 2020a. "An Introduction: The Black Panther Party and Acupuncture?" Of Part and Parcel, February 20, 2020. https://www.ofpartandparcel.com/blog-2/ an-introduction-the-black-panther-party-and-acupuncture.

Meng, Eana. 202ob. "Needles to Needles!': The Use of Ear Acupuncture for Addiction by Patient-turned-practitioners in the United Kingdom." MPhil dissertation, Cambridge University.

Meng, Eana. 2021a. "Photo Essay: Bringing Acupuncture to the People: Tolbert Small in China and California." Asian Medicine 16, no. 2: 276-94.

Meng, Eana. 2021b. "Reflections on (Re)making History: African American Acupuncturists and the Archives of Tolbert Small." Asian Medicine 16, no. 2: 295-309.

Montgomery, Ed. 1972. "Bay Panthers Head for China." San Francisco Examiner, March 6, 1972, 1, 12.

Moyers, Bill. 1988. "What a Real President Was Like." Washington Post, November 13, 1988.https://www.washingtonpost.com/archive/opinions/1988/11/13/what-a-real-pre sident-was-like/d483cibe-doda-43b7-bde6-04e10106ff6c/.

Nelson, Alondra. 2011. Body and Soul: The Black Panther Party and the Fight Against Medical Discrimination. Minneapolis: University of Minnesota Press.

"Panthers, Others Off to Red China." 1972. Sun Reporter (San Francisco, CA), March 11, 1972, 2.

Pilgrim, David. 2015. Understanding Jim Crow: Using Racist Memorabilia to Teach Tolerance and Promote Social Justice. Oakland, CA: PM Press.

Plater, Roz. 2020. "First Person Treated for Sickle Cell Disease with CRISPR Is Doing Well." Healthline, July 6, 2020. https://www.healthline.com/health-news/first-person -treated-for-sickle-cell-disease-with-crispr-is-doing-well\#The-treatment.

"Progressive Americans, Led By Panthers, Return from China." 1972. The Black Panther Intercommunal News Service, April 22, 1972, A-C.

Scott, Robert B. 1970. "Health Care Priority and Sickle Cell Anemia." Journal of the American Medical Association. 214, no. 4: 731-34. https://doi.org/10.1001/jama.1970 .03180040039008.

Serwer, Adam. 2014. "Lyndon Johnson Was a Civil Rights Hero: But Also a Racist." MSNBC, April 11, 2014. https://www.msnbc.com/msnbc/lyndon-johnson-civil-rights -racism-msna305591.

Shakur, Mutulu. 2018. "2018 Interview about Acupuncture \& The Opioid Crisis.” Mutulu Shakur, November 19, 2018. http://mutulushakur.com/site/2018/11/acupunc ture-interview/. 
Sivin, Nathan. 1987. Traditional Medicine in Contemporary China: A Partial Translation of Revised Outline of Chinese Medicine (1972): With an Introductory Study on Change in Present Day and Early Medicine. Ann Arbor: Center for Chinese Studies, University of Michigan.

Small, Tolbert J. 1974a. "The Neurophysiological Basis for Acupuncture." American Journal of Acupuncture 2, no. 2: 77-87.

Small, Tolbert J. 1974b. "Acupuncture Anesthesia: A Review." American Journal of Acupuncture 2, no. 3: 147-63.

Small, Tolbert J. 2015. “On Visiting George.” San Francisco Bay View, July 29, 2015. https:// sfbayview.com/2015/o7/on-visiting-george/.

Tyson, Timothy. 2017. The Blood of Emmett Till. New York: Simon \& Schuster.

Wen, Hsiang-Lai, and S.Y.C. Cheung. 1973. "Treatment of Drug Addiction by Acupuncture." Asian Journal of Medicine 9: 138-41.

Wilkerson, Isabel. 2010. The Warmth of Other Suns: The Epic Story of America's Great Migration. New York: Random House.

Woo, Elaine. 2002. "Sheldon Otis, 69; Lawyer Defended Radicals." Los Angeles Times, March 9, 2002. https:/www.latimes.com/archives/la-xpm-2002-mar-o8-me-otis8 -story.html.

Xu, Xiaoqun. 1997. “'National Essence' vs 'Science': Chinese Native Physicians' Fight for Legitimacy, 1912-37." Modern Asian Studies 31, no. 4: 847-77. 